\title{
Pusa Basmati 1121 - a rice variety with exceptional kernel elongation and volume expansion after cooking
}

\author{
Vijaipal Singh ${ }^{1 *}$, Ashok Kumar Singh ${ }^{2^{*}}$, Trilochan Mohapatra ${ }^{3}$, Gopala Krishnan $S^{2}$ and Ranjith Kumar Ellur ${ }^{2}$
}

\begin{abstract}
Pusa Basmati 1121 (PB 1121) is a landmark Basmati rice variety having Basmati quality traits introgressed from traditional Basmati varieties such as Basmati 370 and Type 3. It was released for commercial cultivation in 2003. It possesses extra-long slender milled grains $(9.00 \mathrm{~mm})$, pleasant aroma, and an exceptionally high cooked kernel elongation ratio of 2.5 with a cooked kernel length of up to $22 \mathrm{~mm}$, volume expansion more than four times, appealing taste, good mouth feel and easy digestibility. Owing to its exceptional quality characteristics, it has set new standards in the Basmati rice market. The cumulative foreign exchange earnings through export of PB 1121 since 2008 have been US\$20.8 billion, which has brought prosperity to millions of Basmati farmers. During 2017, the farmers cultivating PB 1121 earned on an average US\$ 1400/ha as against US\$ 650/ha cultivating traditional Basmati, making it a highly profitable enterprise. Currently, PB 1121 is grown in 70\% of the total area under Basmati rice cultivation in India. It is the most common Basmati rice variety in rice grain quality research for developing mapping populations, genetic analyses and molecular mapping of Basmati quality traits. Additionally, it has been widely used in the Basmati rice breeding program across India, because of its superior quality attributes. This article presents an account of development of PB 1121, its major characteristic features and its flagship role in heralding a Basmati rice revolution. The prospective role of PB 1121 in Basmati rice improvement and future Basmati rice research as a whole is also presented.
\end{abstract}

Keywords: Basmati rice, Aroma, Grain and cooking quality, Linear cooked kernel elongation, Pusa Basmati 1121, Molecular mapping, Genomics

\section{Background}

Basmati is one of the unique specialty rice varieties, which has been cultivated for centuries at the foot of Himalayan mountain ranges. Basmati rice was a predominant constituent of the rich and royal menus. Basmati rice has a harmonious combination of defined kernel dimensions, appealing aroma, fluffy texture of cooked rice, high volume expansion during cooking, linear kernel elongation with minimum breadth-wise swelling, palatability, easy digestibility and longer shelf-life (Singh et al. 1988). In India, Basmati rice is primarily grown in the Indo-Gangetic region of north-western region comprising the seven states Punjab, Haryana, Himachal Pradesh, Uttarakhand,

\footnotetext{
* Correspondence: aks_gene@yahoo.com; vp_geneiari@rediffmail.com ${ }^{1} \mathrm{E}-9$, Sector 40, Noida, UP 201303, India

${ }^{2}$ Division of Genetics, ICAR-Indian Agricultural Research Institute, New Delhi 110012, India

Full list of author information is available at the end of the article
}

Jammu and Kathua districts of Jammu and Kashmir, and 27 districts of western Uttar Pradesh. This region has been earmarked as the Geographical Indication (GI) for Basmati rice and the GI status has been conferred to Basmati rice in 2016 (GI No. 145 of the Geographical Indication Registry, Government of India, vide certificate No. 238 dated 15.02.2016). India is the largest cultivator and exporter of Basmati rice, followed by Pakistan. Basmati rice from the Indian subcontinent is highly prized in the international market for its unique grain, cooking and eating quality.

The name 'Basmati' is likely to have originated from the Sanskrit word, bas from 'vasay' connoting aroma; and mati from mayup meaning ingrained from the beginning. Common usage could have resulted in change of vas to bas resulting in Basmati (Singh and Singh 2009). The earliest mention of the word Basmati has been made in the epic "Heer and Ranjha" composed by the Punjabi poet 
Varish Shah in 1766. In a compilation of "Races of Rice in India", Basmati has been differently spelled (Bansmatti, Bansmutty, Bansmati, Bansmuttee and Basmatee) and described as "A race of rice cultivated throughout the erstwhile Punjab" (comprising Punjab, Haryana and Himachal Pradesh), Delhi, Uttrakhand, parts of Uttar Pradesh and Jammu and Kashmir (Anonymous, 1910).

Traditional Basmati varieties are tall, prone to lodging, photoperiod and temperature sensitive and very low yielding (Fig. 1). Therefore, their production and productivity were limited (Singh et al. 2011). Initial research efforts on Basmati rice improvement based on germplasm collection, evaluation and selection led to the identification of a line number $370 / 27$, released as "Basmati 370" for cultivation in 1933 which was the most popular variety for the purpose of export until the late 1980's (Ramaiah and Rao, 1953). However, Basmati rice did not acquire a status of a commercial enterprise until the ICAR-Indian Agricultural Research Institute (ICARIARI), New Delhi popularly known as "Pusa Institute", took the lead to improve the plant type through systematic research spanning five decades starting from the late 1960s (Siddiq et al. 2012). Pioneering research work was carried out at the ICAR-IARI, New Delhi during the 1970s on standardization of protocols for estimating various Basmati quality parameters and analyzing their inheritance pattern (Singh et al., 2004).

The first breakthrough in developing higher-yielding Basmati rice came in 1989, with the release of Pusa Basmati 1 (IET 10364). It was the world's first semi-dwarf, photoperiod-insensitive and high yielding Basmati rice variety developed from the cross between Pusa 150 and Karnal Local. Pusa 150 is a breeding line which was derived through a convergent breeding approach involving several high yielding non-aromatic rice varieties such as Taichung Native 1, IR8, IR22 etc., and traditional Basmati rice variety, Basmati 370, which was used as donor for quality traits. Karnal Local was a selection from the traditional Basmati rice collection, Haryana Basmati

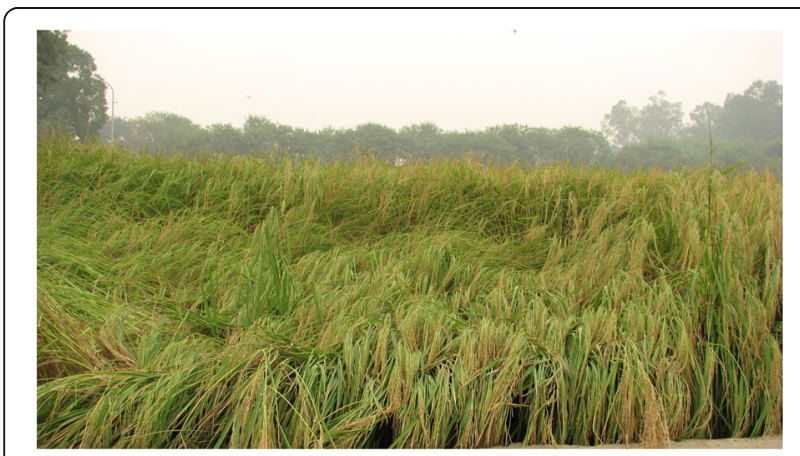

Fig. 1 Lodging in the traditional Basmati rice variety, Type 3 at maturity due to tallness
Collection 19 (HBC 19) from the Karnal district of Haryana with better grain and cooking quality, which was later released as Taraori Basmati in 1996 (Singh et al. 2004). It was one of the most widely used parents by rice breeders for grain, cooking and eating characteristics. The International Rice Research Institute (IRRI) used it in as many as 249 crosses (Singh and Singh, 2010). Extra-long slender aromatic grains, less cooking time and higher linear cooked kernel elongation of freshly harvested rice coupled with a potential grain yield of 5.0 tons/ha and medium early duration (135-140 days seed to seed maturity) made Pusa Basmati 1 the most sought after variety by the farmers, exporters and consumers. During the 1990's, ICAR-IARI gave priority to longer grain length and higher linear cooked kernel elongation during cooking in addition to other Basmati attributes and a decade of focused work resulted in the development of Pusa Basmati 1121.

\section{Breeding history}

A brief account of the development of Pusa Basmati 1121 has been documented by Singh et al. (2002). During Kharif (rainy season/ wet season) 1991, a cross involving advanced breeding lines, Pusa 614-1-2 and Pusa 614-2-4-3, derived from traditional Basmati varieties such as Basmati 370 and Type 3 in it pedigree, was made with the objective of improving grain length and linear cooked kernel elongation at ICAR-IARI, New Delhi (Fig. 2). In Kharif 1992, a large number of single plant selections was made from the $F_{2}$ population. One of these possessed longer milled rice kernels and showed exceptionally high linear cooked kernel elongation. Although the linear cooked kernel elongation

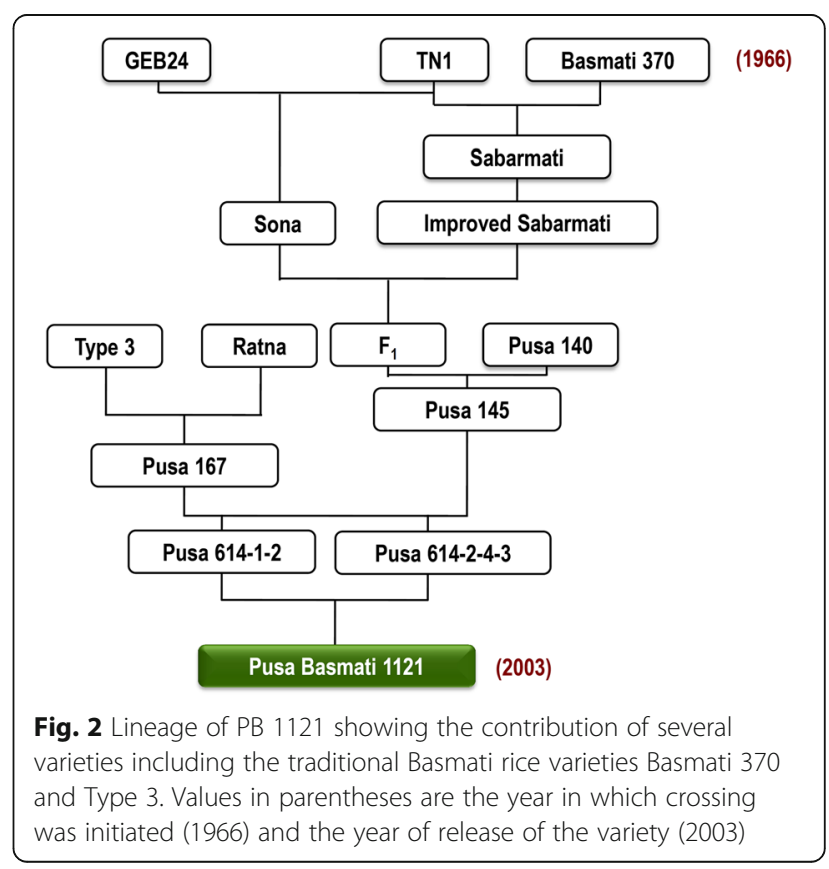


and aroma were stable, there was still variation for brown rice grain dimension, breadth and texture of cooked rice and bursting during cooking in the subsequent generations. Several rounds of stringent phenotypic selection in the following generations helped in stabilizing the line for milled rice kernel length, aroma and its exceptional cooking quality. One of the superior lines, Pusa 1121-92-8-13-3 (IET 18004) was entered into the Basmati trials (presently the National Basmati Trials) under the All India Coordinated Research Project on Rice in 2002. It was released for commercial cultivation in the national capital region of Delhi in 2003, and subsequently for the states of Punjab and Haryana in 2008 (vide gazette notification no. S.Q. 2547(E), Ministry of Agriculture, Government of India dated 29th October, 2008).

The superior linear cooked kernel elongation in $\mathrm{PB}$ 1121 was derived from parents Basmati 370 and Type 3, which were used as donors for grain and cooking quality traits. The accumulation of favorable loci for extra-long grain and exceptionally high linear cooked kernel elongation was possible through transgressive segregation resulting from selective inter-mating of the sister lines showing better linear kernel elongation in the segregating generations. The lineage of PB 1121 (Fig. 2) clearly shows that as many as 13 rice varieties/enhanced germplasm, including the traditional Basmati rice varieties such as Basmati 370 and Type 3 were used to bring together the favorable alleles at multiple loci for agronomic, grain and cooking quality characteristics in development of PB 1121.

\section{Key agronomic and quality traits}

PB 1121 is a semi-dwarf rice variety with a plant height ranging from 110 to $120 \mathrm{~cm}$ (Fig. 3a). The $s d 1$ allele for reduced plant height was derived from Taichung Native 1. It has a seed to seed maturity of 140-145 days in the Basmati growing regions of India. PB 1121 has a yield potential of up to 5.5 tons per hectare. It can produce 18-20 tillers per plant at a spacing of $20 \mathrm{~cm} \times 15 \mathrm{~cm}$ and around $350-400$ panicles per $\mathrm{m}^{2}$. It possesses well exserted long panicles, ranging from 26 to $28 \mathrm{~cm}$. The number of filled grains per panicle ranges from 105 to 110 and the 1000-grain weight of the fully mature grains is $27.0-28.0 \mathrm{~g}$ (at $14 \%$ moisture). Since Basmati grains are extra-long and slender in appearance, they are prone to breakage during machine harvesting. Therefore, manual threshing in Basmati rice is preferred as it results in reduced broken grains, high head rice recovery and better price realization for farmers as compared to a machine harvested crop. PB 1121 has easy threshability, which is advantageous for manual threshing by the farmers.

The key grain characteristics of PB 1121 are presented in Table 1. It has extra-long slender grains with a milled

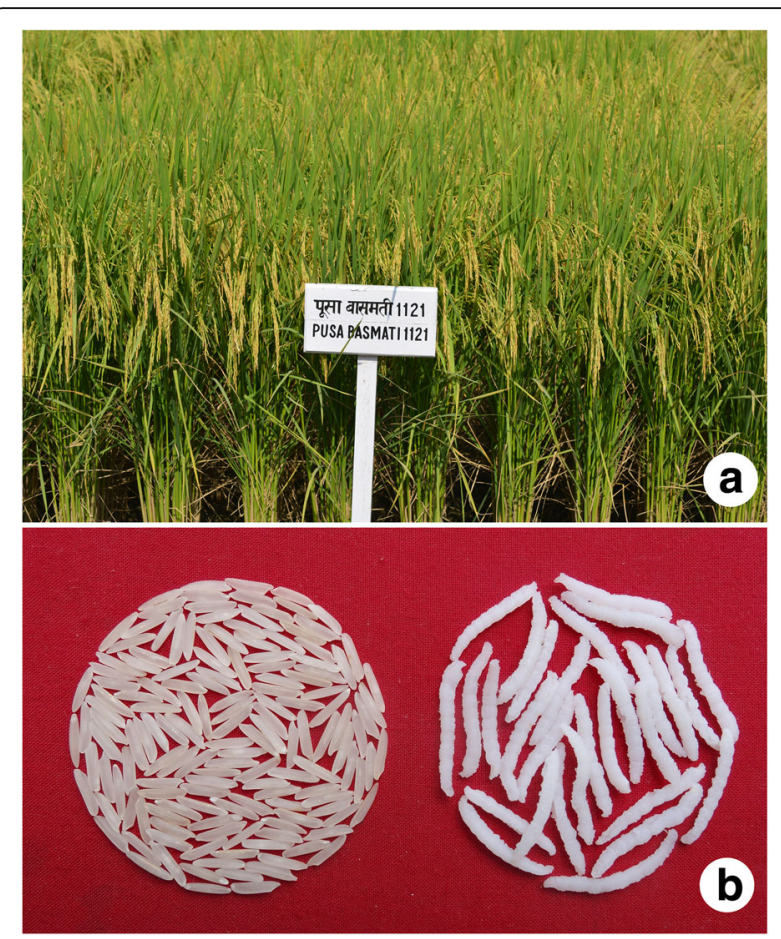

Fig. 3 a Field view of the plot of PB 1121 at ICAR-IARI, New Delhi, (b) Milled rice and cooked rice kernels of PB 1121

rice kernel length averaging $9.00 \mathrm{~mm}$, a breadth of 1 . $90 \mathrm{~mm}$ and an L/B ratio of 4.74 (Fig. 3b). Despite extralong slender grains, it has an appreciable head rice recovery of $54.5 \%$ with a hulling and milling percentage of 75.0 and 70.5, respectively. The brown rice of PB 1121 is tan in colour. The alkali spreading value (ASV) score is 7 and the amylose content is $22.0 \%$. The linear cooked kernel length of PB 1121 is another unique feature, which is the highest ever recorded in rice germplasm, ranging from 21 . 0 to $21.5 \mathrm{~mm}$ with minimum breadthwise swelling (only $2.45 \mathrm{~mm}$ ). The kernel elongation ratio of 2.70 is also the highest ever known for any rice line. It also possesses strong aroma and has been rated as excellent cooking in the panel test (Additional file 1: Table S2).

\section{Improvement in PB 1121 as compared to traditional Basmati rice varieties}

\section{Duration and productivity}

Basmati rice research work carried out at ICAR-IARI, New Delhi has resulted in reduction of growth duration from 160 days in traditional Basmati to $140-145$ days. Combined with the doubling of the yield from $2.5 \mathrm{t} / \mathrm{ha}$ to $5.0 \mathrm{t} / \mathrm{ha}$, this results in higher per day productivity and saving of inputs like fertilizer, irrigation and pesticides thus bringing down the cost of cultivation (Fig. 4) and giving more turnaround time to farmers for timely sowing of wheat, which is a very important winter 
Table 1 Grain and cooking quality characteristics of improved Basmati rice variety PB 1121 compared to Basmati 370, Taraori Basmati and Pusa Basmati 1

\begin{tabular}{|c|c|c|c|c|c|c|}
\hline Variety & Milling\% & HRR\% & $\mathrm{KLBC}(\mathrm{mm})$ & $\mathrm{KBBC}(\mathrm{mm})$ & $\mathrm{KLAC}(\mathrm{mm})$ & $\overline{E R}$ \\
\hline Basmati 370 & 72.5 & 53.0 & 6.89 & 1.85 & 13.40 & 1.94 \\
\hline Taraori Basmati & 69.0 & 49.9 & 7.15 & 1.78 & 13.97 & 1.95 \\
\hline Pusa Basmati 1 & 67.0 & 48.5 & 7.38 & 1.80 & 14.75 & 2.00 \\
\hline PB 1121 & 70.5 & 54.5 & 8.00 & 1.90 & 21.50 & 2.69 \\
\hline
\end{tabular}

HRR-Head rice recovery, KLBC-Kernel length before cooking, KBBC - Kernel breadth before cooking, KLAC-Kernel length after cooking, ER-Elongation ratio (Source: Singh et al. 2002)

season crop in the rice-wheat cropping system of northwestern India.

\section{Grain and cooking quality}

Systematic breeding efforts at ICAR-IARI, New Delhi has helped in improving the grain and cooking quality in PB 1121 as compared to other Basmati rice varieties released earlier (Table 1, Fig. 5). The most striking characteristic feature of $\mathrm{PB} 1121$ as compared to other Basmati rice varieties is its kernel length after cooking, which is $21.50 \mathrm{~mm}$. There has been an improvement in the milled rice kernel length to 8 . $00 \mathrm{~mm}$ as compared to $6.89 \mathrm{~mm}$ in Basmati 370. As a result of its improved kernel elongation, the volume expansion in the cooked rice is more than 4.0 times. This helps in realizing more cooked rice volume with lesser milled rice, a trait most preferred in the household as well as the hotel industry.

\section{Adoption and impact}

Owing to its higher yield and unique grain and cooking quality traits, PB 1121 received phenomenal acceptance in the domestic as well as global market encouraging the millers to pay a premium price to the farmers. The area under Basmati rice cultivation increased from 0.78 million hectares (mha) in 2004 to
2.12 mha in 2015, in which the PB1121 is cultivated on about $70 \%$ of the total area (Fig. 6a, Additional file 1: Table S1). The total Basmati rice produced during Kharif 2016 was 6.16 million tones (mt), of which PB 1121 contributed $4.39 \mathrm{mt}(\sim 68 \%)$ (Fig. 6b, Additional file 1: Table S1). Average net income due to cultivation of PB 1121 is about US\$ 1400/ha compared to US\$ 650/ha from traditional Basmati rice varieties such as Basmati 370 and Taraori Basmati in 2017 (Unpublished data).

Basmati rice fetches a premium price in the international market. The total foreign exchange earning of Basmati rice prior to release of Pusa Basmati 1121 was US\$ 440 million (during 2003-04). Owing to the superior cooking quality traits of Pusa Basmati 1121, the annual foreign exchange earning of Basmati rice has surged during 2013-14 to US\$ 4.87 billion, in which the contribution of PB 1121 was US \$ 3.41 billion $(\sim 70 \%)$ (Fig. 7). The approximate cumulative earning due to export of PB 1121 and its domestic share from 2008 to 2016 has been estimated to be about US \$ 20.80 billion. An analysis of the impact of PB 1121 on Basmati exports shows that while the volume of Basmati rice exports has increased by 4.4 times, the value has increased by 6.8 times after the release of $\mathrm{PB} 1121$ compared to the same period before the release of PB 1121 (Fig. 8).

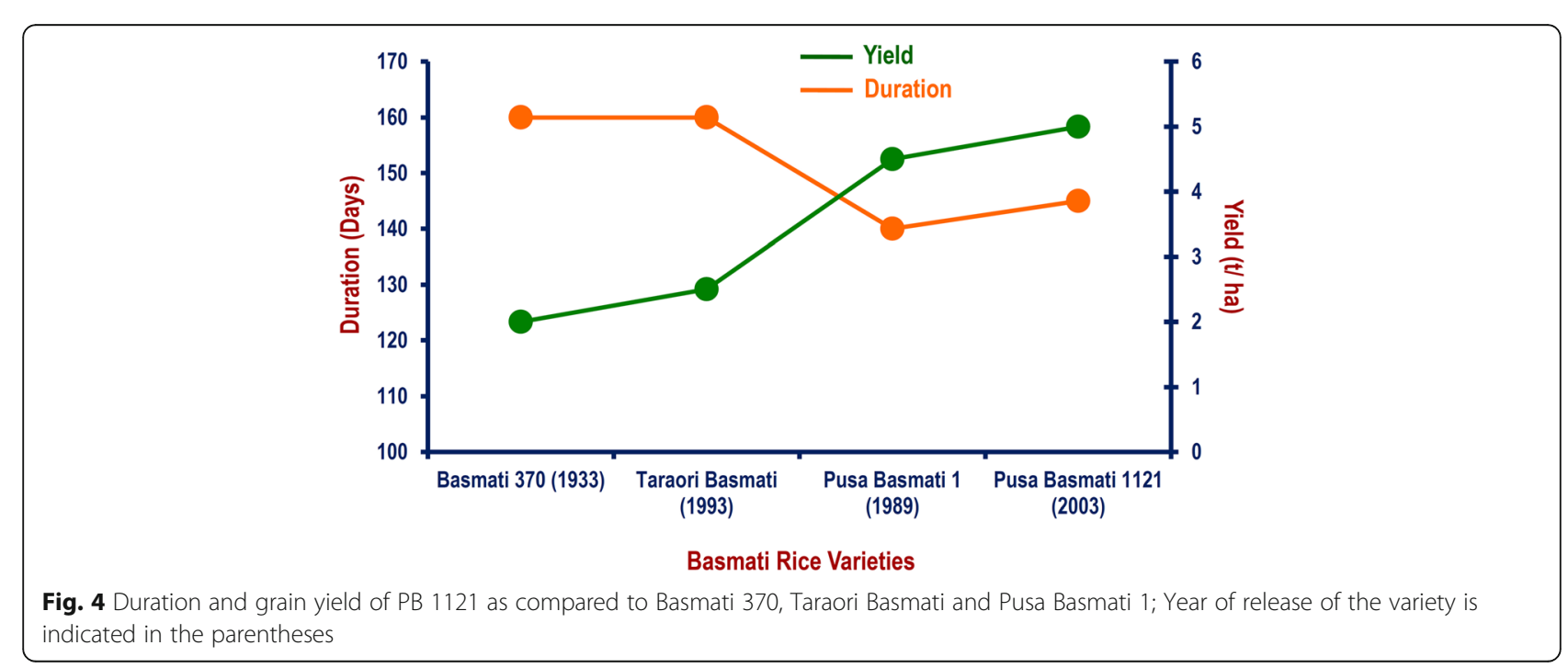




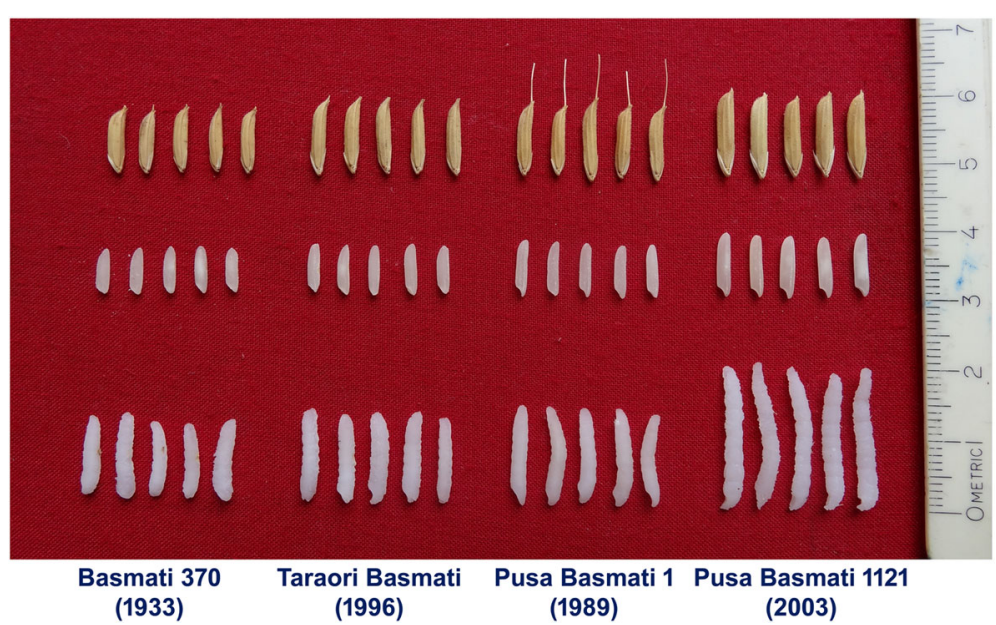

Fig. 5 Gradual improvement in grain and cooking quality of Basmati rice varieties: a journey of decades

\section{PB 1121 in genetic and molecular mapping}

PB 1121 provides unique phenotypes for milled rice kernel length and linear cooked kernel elongation. Therefore, it has been used by various researchers in developing populations for the mapping and validation of quantitative trait loci (QTL) governing grain length, cooked kernel elongation, aroma, and other traits, which is summarized in Table 2 and Fig. 9. Amarawathi et al. (2008) mapped QTLs

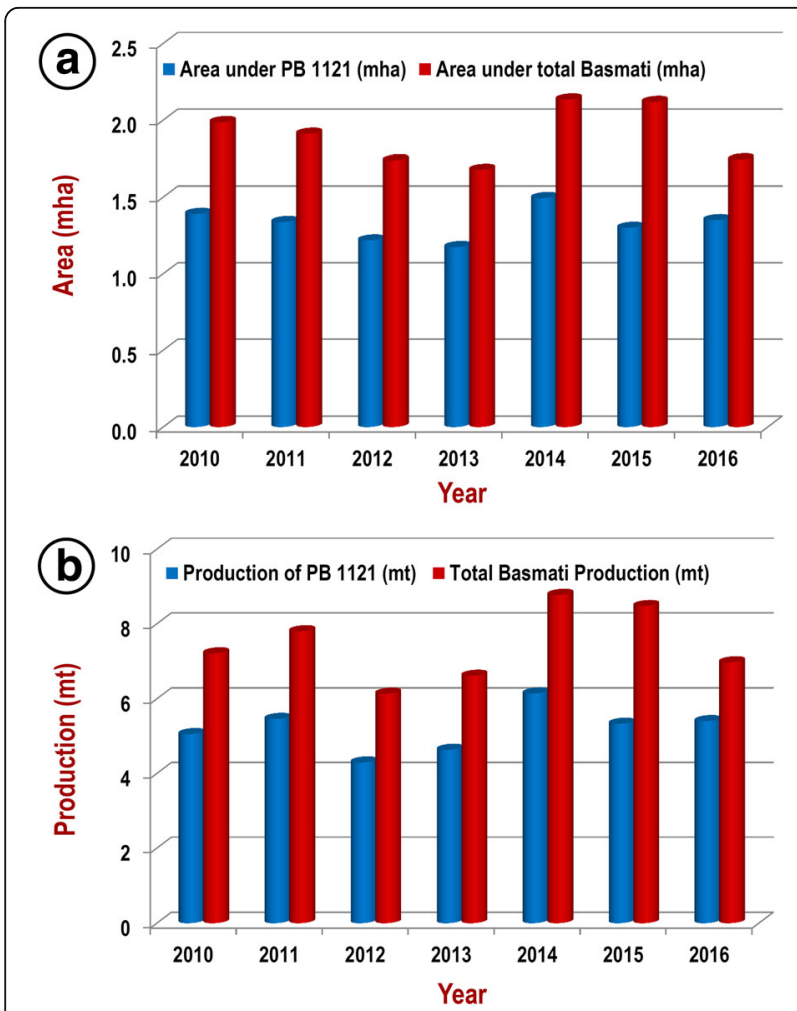

Fig. 6 Area (a) and yield (b) of Pusa Basmati 1121 compared to the totals for all Basmati rice governing grain length on chromosomes 1 (grll-1) and 7 (grl7-1) using a recombinant inbred line (RIL) population from the cross PB 1121/Pusa 1342, which were further fine mapped to a region of $108 \mathrm{~kb}$ and $2.39 \mathrm{Mb}$, respectively (Singh et al. 2012). QTL mapping using an $\mathrm{F}_{2}$ population from a short grain aromatic rice genotype, Sonasal and PB 1121 identified another major QTL on chromosome 3, which co-localized with GS3. Molecular analysis using a functional marker, SF28 for the gene GS3, revealed the presence of a C-A mutation in exon 2 in PB 1121 (Singh et al. 2011). Three QTLs governing aroma, aro3-1, aro4-1 and aro $8-1$ were identified using the same population, out of which aro3-1 and aros-1 were fine mapped to $390 \mathrm{~kb}$ and $430 \mathrm{~kb}$ intervals (Singh et al. 2007). Based on whole genome re-sequencing, we have confirmed the presence of an 8 bp deletion in the Badh2 locus governing aroma in PB 1121. It is highly susceptible to bakanae disease and has been used in mapping a major QTL ( $q B K 1.2)$ governing resistance to this disease of rice (Fiyaz et al. 2016). Among the genes identified for grain quality, GS3 for grain length and $B a d h 2$ for aroma, and two major QTLs, qBK1.1, qBK1.2 governing resistance to bakanae disease, have been validated and the markers associated with these genes/QTLs are being used in marker assisted improvement of Basmati rice.

\section{Genomic characterization of PB 1121}

Whole genome sequencing using next-generation sequencing technologies helps in the discovery of key polymorphisms in crops such as rice, where a high quality reference sequence is available (Krishnan et al. 2012). The whole genome of PB 1121 was sequenced using Illumina Hiseq 2500 platform. A total of 124 million high quality reads with an average read length of $100 \mathrm{bp}$ were obtained, and the average sequencing depth was 50X. We mapped 122.29 million (98.03\%) reads to the 


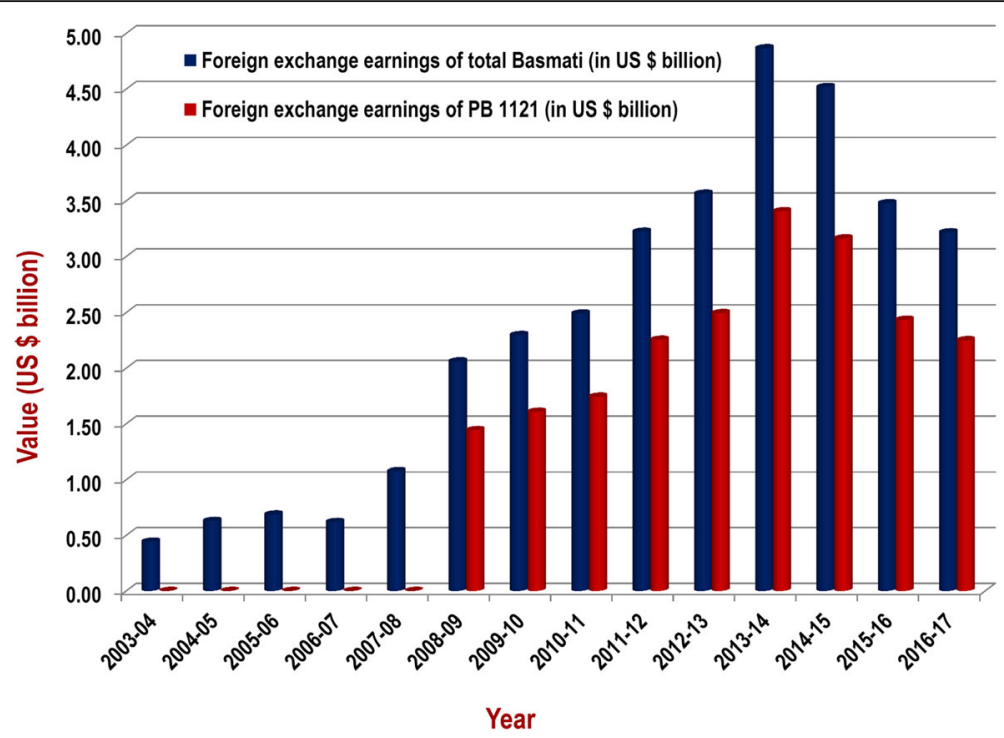

Fig. 7 Trends in foreign exchange earnings through export of Basmati rice since the release of Pusa Basmati 1121 (Source: http://agriexchange.apeda.gov.in/indexp/reportlist.aspx)

Oryza sativa L. cv. Nipponbare reference genome. A total of 82.2 million reads were uniquely mapped to chromosomes, 0.53 million reads possessed secondary alignments and 1.92 million reads were unmapped.

A total of 3,036,468 variants $(2,765,215$ SNPs and 292,003 InDels) were identified with average variant rate ranging from $91 \mathrm{bp}$ on chromosome 10 to $163 \mathrm{bp}$ on chromosome 2 (Additional file 1: Table S2). The number of transitions was comparatively higher than that of transversions with $T s / T v$ ratio of 2.50 . The annotation of variants revealed $56.24 \%$ of variants to be missense and $2.10 \%$ of variants to be nonsense, and the remaining 41 . $66 \%$ were silent mutations. A total of $85.54 \%$ of the

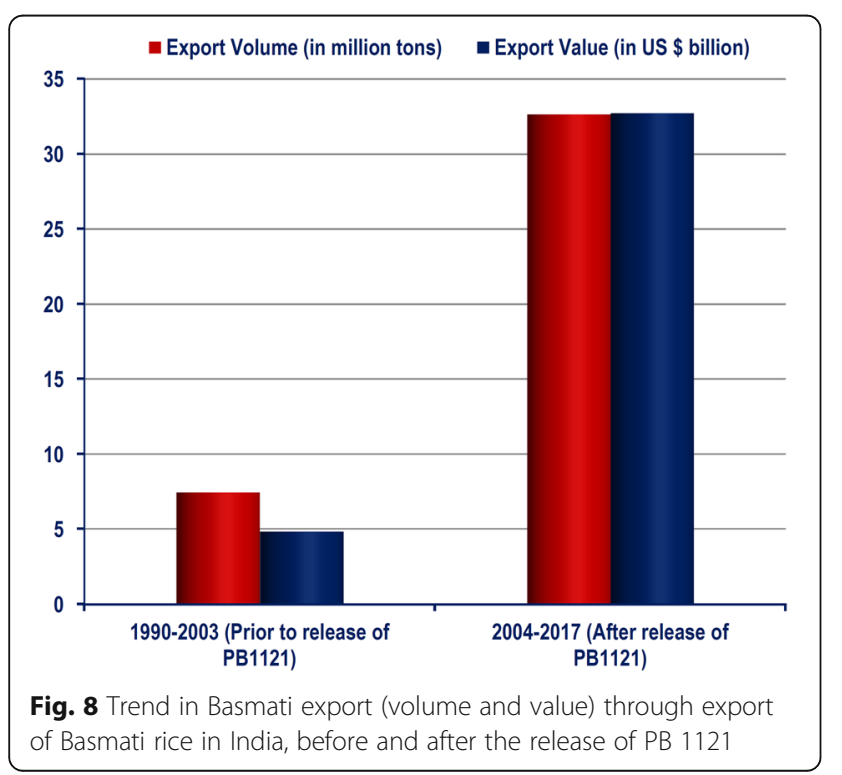

variations were found in non-genic regions while, 14 . $46 \%$ of variations were found in genic regions. PB 1121 possesses extra-long slender grains along with strong aroma and alkali spreading value of 7 . Haplotype analysis revealed presence of the long grain specific haplotype with CTGAAG in the second exon of GS3, which governs grain length in rice; the 8 bp deletion was found in Badh2, which governs aroma; and a haplotype of $\mathrm{G}_{6752756}-\mathrm{T}_{6752887} \mathrm{~T}_{6752888}$ was found in the ALK gene which governs alkali spreading value of rice.

\section{Important varieties and genotypes developed using PB 1121 as a parent}

PB 1121 has been used extensively as a parent in conventional breeding to develop better Basmati rice varieties including Pusa Basmati 6 and Pusa Basmati 1509 which have been released for commercial cultivation in the years 2008 and 2013, respectively (Fig. 10).

\section{Pusa Basmati 6}

Also known as Pusa 1401, it has semi-dwarf plant stature with sturdy stem and yields up to $7 \mathrm{t} / \mathrm{ha}$ in farmers' fields. The cooked kernel of Pusa Basmati 6 has uniform shape, as compared to that with a tapering end in $\mathrm{PB}$ 1121. It also possesses strong aroma and minimum chalkiness $(<4 \%)$.

\section{Pusa Basmati 1509}

A semi-dwarf early maturing Basmati rice variety, which has been released for the national capital region of Delhi, Uttar Pradesh and Punjab (Singh et al. 2014). Pusa Basmati 1509 has a semi-dwarf plant stature (plant height of $95-100 \mathrm{~cm}$ ), and therefore it is resistant to lodging. It 
Table 2 Mapping populations developed using PB 1121 for mapping and validation of QTLs governing various traits in rice

\begin{tabular}{|c|c|c|c|c|c|c|}
\hline $\begin{array}{l}\text { S. } \\
\text { No. }\end{array}$ & Trait(s) mapped & $\begin{array}{l}\text { Mapping population } \\
\text { (Population used) }\end{array}$ & QTLs mapped & $\begin{array}{l}\text { Marker interval/ linked } \\
\text { marker }\end{array}$ & $\begin{array}{l}\text { Percent phenotypic variance } \\
\text { (PVE \%) }\end{array}$ & Reference \\
\hline \multicolumn{7}{|c|}{ (a) Mapping of QTLs for grain and cooking quality traits } \\
\hline \multirow[t]{3}{*}{1.} & \multirow[t]{3}{*}{ Grain length } & \multirow[t]{3}{*}{ PB 1121/Pusa 1342 (RILs) } & grll-1 & RM431-RM104 & 10.10 & \multirow{3}{*}{$\begin{array}{l}\text { Amarawathi } \\
\text { et al. } 2008\end{array}$} \\
\hline & & & $g r \mid 7-1$ & RM11-RM505 & 7.40 & \\
\hline & & & grl7-2 & RM505-RM336 & 5.70 & \\
\hline \multirow[t]{2}{*}{2.} & \multirow[t]{2}{*}{ Grain breadth } & \multirow[t]{2}{*}{ PB 1121/Pusa 1342 (RILs) } & grb7-1 & RM11-RM505 & 10.10 & \\
\hline & & & grb7-2 & RM505-RM336 & 18.90 & \\
\hline \multirow[t]{2}{*}{3.} & \multirow[t]{2}{*}{ Length/ breadth ratio } & \multirow[t]{2}{*}{ PB 1121/Pusa 1342 (RILs) } & $1 b r 7-1$ & RM11-RM505 & 10.00 & \\
\hline & & & $16 r 7-2$ & RM505-RM336 & 21.90 & \\
\hline 4. & Elongation ratio & PB 1121/Pusa 1342 (RILs) & elrl11-1 & RM1812-RM209 & 6.80 & \\
\hline 5. & Amylose content & PB 1121/Pusa 1342 (RILs) & amy6-1 & RM3-RM217 & 39.60 & \\
\hline 6. & ASV & PB 1121/Pusa 1342 (RILs) & asv6-1 & RM3-RM217 & 6.90 & \\
\hline \multirow[t]{3}{*}{7.} & \multirow[t]{3}{*}{ Aroma } & \multirow[t]{3}{*}{ PB 1121/Pusa 1342 (RILs) } & aro3-1 & RM5474-RM282 & 10.30 & \\
\hline & & & $\operatorname{aro} 4-1$ & RM5633-RM273 & 6.10 & \\
\hline & & & aro8-1 & RM223-RM80 & 18.90 & \\
\hline \multirow[t]{3}{*}{8.} & \multirow[t]{3}{*}{$\begin{array}{l}\text { Resistance to bakanae } \\
\text { disease }^{\text {a }}\end{array}$} & \multirow[t]{3}{*}{ PB 1121/Pusa 1342 (RILs) } & $q B K 1.1$ & RM9-RM11282 & 6.49 & \multirow[t]{3}{*}{$\begin{array}{l}\text { Fiyaz et al. } \\
2016\end{array}$} \\
\hline & & & $q B K 1.2$ & RM10153-RM5336 & 24.70 & \\
\hline & & & $q B K 1.3$ & RM10271-RM35 & 4.70 & \\
\hline \multicolumn{7}{|c|}{ (b) Fine mapping of QTLs and allele mining } \\
\hline \multirow[t]{2}{*}{9.} & \multirow[t]{2}{*}{ Aroma } & \multirow[t]{2}{*}{ PB 1121/Pusa 1342 (RILs) } & aro3-1 & CHR3_22-CHR3_24 & 11.00 & \multirow[t]{2}{*}{$\begin{array}{l}\text { Singh et al. } \\
2007\end{array}$} \\
\hline & & & aros-1 & CHR8_49-RM44 & 2.90 & \\
\hline \multirow[t]{4}{*}{10.} & \multirow[t]{4}{*}{ Grain length } & \multirow[t]{4}{*}{ PB 1121/Pusa 1342 (RILs) } & qGRL7.1 & CHR7_34-RM505 & 15.20 & \multirow[t]{4}{*}{$\begin{array}{l}\text { Singh et al. } \\
2012\end{array}$} \\
\hline & & & qGRL1.1 & CHR1_1-RM431 & 10.80 & \\
\hline & & & qGRB7.1 & CHR7_34-RM505 & 8.60 & \\
\hline & & & qLBR7.1 & CHR7_34-RM505 & 8.60 & \\
\hline 11. & Grain length & Sonasal/PB 1121 (RILs) & $\begin{array}{l}\text { Novel InDel in } \\
\text { GS3 }\end{array}$ & aks-GS3-12 & - & $\begin{array}{l}\text { Anand et al. } \\
2015\end{array}$ \\
\hline \multicolumn{7}{|c|}{ (c) Validation of QTLs } \\
\hline \multirow[t]{4}{*}{12.} & \multirow[t]{4}{*}{ Grain length } & Sonasal/PB $1121\left(F_{2}\right)$ & GS3 & SF28 & 32.50 & $\begin{array}{l}\text { Anand et al. } \\
2013\end{array}$ \\
\hline & & & GS3 & SR17 & 7.90 & \\
\hline & & & GS3 & RGS1 & 12.00 & \\
\hline & & & GS3 & RGS2 & 6.30 & \\
\hline 15. & Grain length & Sonasal/PB $1121\left(F_{2}\right)$ & $9 g r 17.1$ & RM505 & 5.40 & $\begin{array}{l}\text { Anand et al. } \\
2013\end{array}$ \\
\hline
\end{tabular}

${ }^{\mathrm{a}}$ PB 1121 is used as a susceptible parent

has a 120 days seed to seed maturity, the shortest duration for any Basmati rice variety released so far. The variety produces an average yield of $4.1 \mathrm{t} / \mathrm{ha}$ with yield levels as high as $7.0 \mathrm{t} / \mathrm{ha}$ under good management. Quality wise, this variety possesses aromatic extra-long slender grains $(8.41 \mathrm{~mm})$ with very occasional grain chalkiness, very good kernel length after cooking (19.1 mm), desirable ASV (7.0) and intermediate amylose content (21.2\%).

\section{Pusa Basmati 1718}

Pusa Basmati 1718 (PB 1718) is a marker-assisted selection (MAS) derived near-isogenic line of PB 1121 possessing two genes governing resistance to $\mathrm{BB}$ disease, $x a 13$ and Xa21 (Singh et al. 2018). It has a seed to seed maturity of 136-138 days and average yield of $4.64 \mathrm{t} / \mathrm{ha}$. It has been released and notified for the states of Punjab, Haryana and Delhi of the Basmati growing region of the country. It 


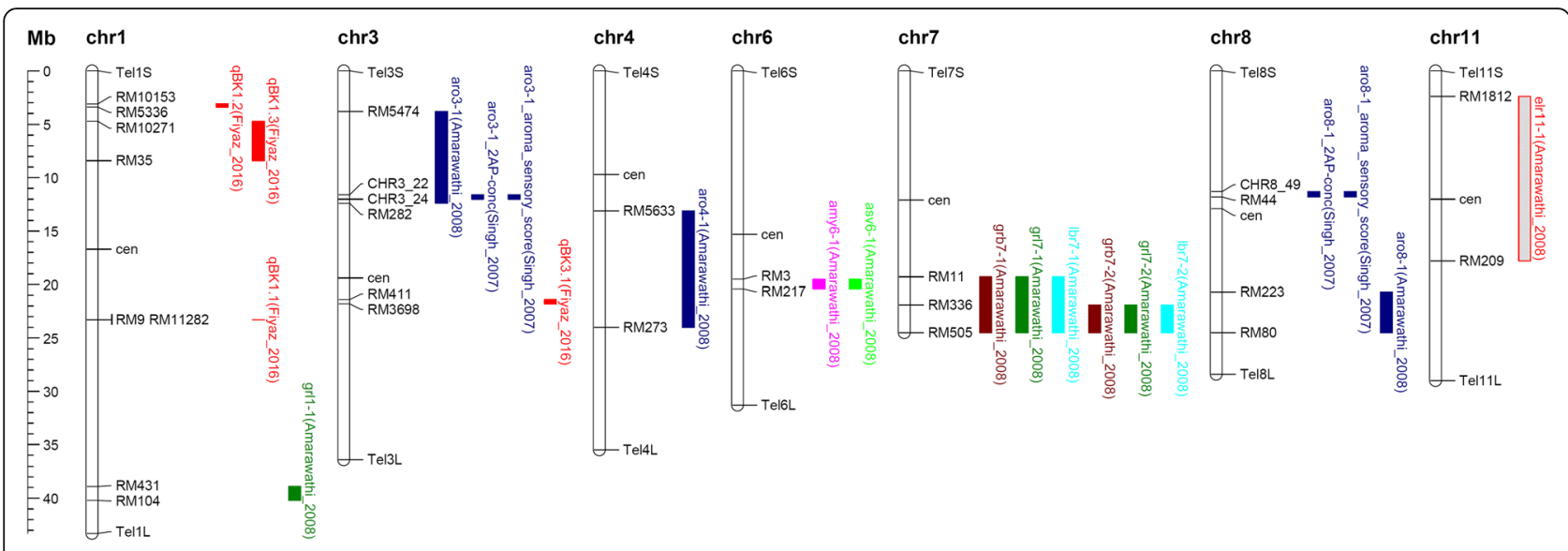

Fig. 9 QTLs mapped for various traits in different chromosomes using PB 1121 as one parent in development of a mapping population

shows resistance to $\mathrm{BB}$ with a susceptibility index (SI) of 2 as compared to 7.7 of PB 1121, which is highly susceptible in Basmati growing regions. PB 1718 possesses long slender grains $(8.1 \mathrm{~mm})$ with very little grain chalkiness, very good kernel length after cooking $(17.0 \mathrm{~mm})$, intermediate amylose content (22.2\%) and strong aroma.

Since, PB 1121 occupies a major share in Basmati rice cultivation and export, ICAR-IARI has a major program on improving this variety for resistance to different biotic stresses, namely, BB, blast and abiotic stresses such as seedling stage salt tolerance through precise transfer of gene(s)/QTLs governing these traits with the aid of molecular marker assisted improvement (Table 3).

\section{Conclusions}

Overall, the Basmati rice research work carried out at ICAR-IARI has resulted in reducing the crop duration from 160 days in traditional Basmati to 140-145 days in PB 1121, combined with doubling the yield from $2.5 \mathrm{t} /$ ha to nearly $5.0 \mathrm{t} / \mathrm{ha}$. This has immensely helped in creating employment in the Basmati growing region, which has resulted in the establishment of more modern rice mills and making available better quality Basmati rice for the domestic and global market on a regular basis. It has greatly improved the economics of Basmati rice cultivation, and also the entire value chain of the Basmati rice industry, especially exporters and consumers thereby ushering in a Basmati rice revolution.

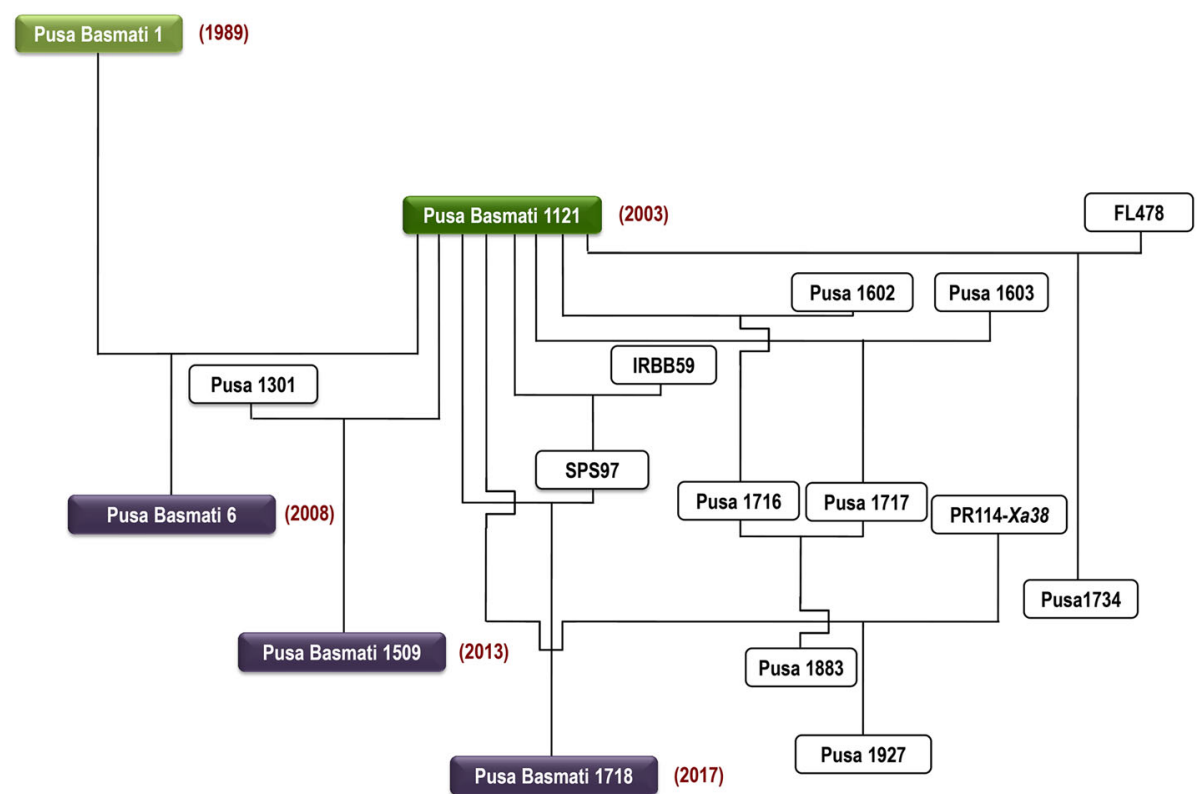

Fig. 10 Important Basmati rice varieties and improved Basmati rice genotypes derived from PB 1121 
Table 3 Basmati rice varieties developed using PB 1121, along with characteristic features of the trait (genes incorporated) that has been improved

\begin{tabular}{|c|c|c|c|c|c|}
\hline $\begin{array}{l}\text { S. } \\
\text { No. }\end{array}$ & $\begin{array}{l}\text { Name of the } \\
\text { Basmati Rice } \\
\text { Variety/ Genotype }\end{array}$ & $\begin{array}{l}\text { Year of } \\
\text { Release }\end{array}$ & Pedigree & Special attribute(s) & $\begin{array}{l}\text { Area for which it is } \\
\text { Recommended for Cultivation }\end{array}$ \\
\hline \multicolumn{6}{|c|}{ Released varieties } \\
\hline & Pusa Basmati 6 & 2008 & $\begin{array}{l}\text { Pusa Basmati } \\
\text { 1/PB } 1121\end{array}$ & $\begin{array}{l}\text { Milled rice less than } 4 \% \text { chalky grains, cooked rice uniform in } \\
\text { shape, strong aroma }\end{array}$ & $\begin{array}{l}\text { Basmati growing areas of Punjab, } \\
\text { Haryana, Delhi, Uttarakhand and } \\
\text { Uttar Pradesh }\end{array}$ \\
\hline & Pusa Basmati 1509 & 2013 & $\begin{array}{l}\text { Pusa 1301/PB } \\
1121\end{array}$ & $\begin{array}{l}\text { Semi-dwarf early maturing Basmati rice variety with a seed to } \\
\text { seed maturity of } 120 \text { days with grain quality comparable to PB } \\
1121\end{array}$ & $\begin{array}{l}\text { Basmati growing areas of Uttar } \\
\text { Pradesh, Punjab and Delhi (Singh } \\
\text { et al. 2014) }\end{array}$ \\
\hline & Pusa Basmati 1718 & 2017 & $\begin{array}{l}\text { PB 1121/SPS } \\
97 / / \mathrm{PB} \\
1121 * 3\end{array}$ & $\begin{array}{l}\text { A MAS derived bacterial blight resistant near-isogenic line of } \\
\text { PB } 1121 \text { possessing two genes governing resistance to bacter- } \\
\text { ial blight disease, xa13 and Xa21 }\end{array}$ & $\begin{array}{l}\text { Basmati growing areas of Punjab, } \\
\text { Haryana and Delhi (Singh et al. } \\
\text { 2018) }\end{array}$ \\
\hline \multicolumn{6}{|c|}{ Improved PB 1121 genotypes } \\
\hline & Pusa 1883 & - & $\begin{array}{l}\text { Pusa 1716/ } \\
\text { Pusa } 1717\end{array}$ & $\begin{array}{l}\text { A MAS derived blast resistant near-isogenic line of PB } 1121 \\
\text { possessing two genes governing resistance to blast disease } \\
\text { namely, Pi2 and Pi54 }\end{array}$ & Not yet released. (Ellur et al. 2016) \\
\hline & Pusa 1927 & - & $\begin{array}{l}\text { PB } 1121 / \\
\text { PR114-Xa38// } \\
\text { PB } 1121 * 2\end{array}$ & $\begin{array}{l}\text { A MAS derived bacterial blight resistant near-isogenic line of } \\
\text { PB } 1121 \text { possessing BB resistance gene, Xa38 governing resist- } \\
\text { ance to bacterial blight disease }\end{array}$ & Not yet released. (Ellur et al. 2016) \\
\hline & Pusa 1734 & - & $\begin{array}{l}\text { PB } 1121 / \\
\text { FL478/PB } \\
1121 * 3\end{array}$ & $\begin{array}{l}\text { A MAS derived near-isogenic line of PB } 1121 \text { possessing } \\
\text { "Saltol", a major QTL governing tolerance to salt stress at seed- } \\
\text { ling stage }\end{array}$ & $\begin{array}{l}\text { Not yet released. (Babu et al. } \\
\text { 2017) }\end{array}$ \\
\hline
\end{tabular}

However, Basmati rice cultivation is facing several challenges from diseases such as bacterial blight, bakanae, neck blast, and insect pests like brown plant hopper and stem borer. Therefore, breeding Basmati cultivars with resistance to these diseases, pests and other abiotic stresses while maintaining the superior grain quality by reducing chalkiness, improving HRR and better aroma is the major focus for Basmati rice improvement.

In this endeavour, PB 1718, a bacterial blight resistant near isogenic line of PB 1121, has been developed and released for commercial cultivation in 2017 (Singh et al. 2018). In order to sustain Basmati rice cultivation, it is pertinent to continuously improve the iconic rice variety such as PB 1121, and efforts are already underway to pyramid resistance to bacterial blight, blast and bakanae diseases. The whole genome re-sequencing of $\mathrm{PB} 1121$ has been accomplished which will help in better understanding the genetic and molecular basis of the complex nature of the Basmati grain and cooking quality in $\mathrm{PB} 1121$, and open up new areas of research in Basmati rice, thereby providing an altogether new dimension to Basmati rice breeding. Pyramiding gene(s)/QTL(s) governing resistances to major biotic and tolerance to abiotic stresses, while retaining the premium grain and cooking quality of Basmati rice will go a long way in overcoming the problem of potential risks of the pesticide residue and reducing the cost of cultivation.

\section{Additional file}

Additional file 1: Table S1 Area and production of total Basmati rice vis a vis PB 1121. Table S2 Panel test scores of PB 1121 as compared to Taraori Basmati and Pusa Basmati 1. Table S3 Reads mapped and variants discovered from whole genome re-sequencing of PB 1121. (DOC $61 \mathrm{~kb})$

\section{Abbreviations}

ASV: Alkali spreading value; BB: Bacterial blight; GI: Geographical Indication; HBC 19: Haryana Basmati Collection 19; ICAR-IARI: ICAR- Indian Agricultural Research Institute; IET: Initial Evaluation Trial; InDels: Insertion and Deletions; IRRI: International Rice Research Institute; IRRN: International Rice Research Newsletter; L/B: Length/ Breadth; MAS: Marker assisted selection; mha: Million hectares; mt: Million tones; PB 1121: Pusa Basmati 1121; PB 1718: Pusa Basmati 1718; QTL: Quantitative trait loci; RIL: Recombinant inbred line; SNPS: Single nucleotide polymorphisms

\section{Funding}

The research work on Basmati rice improvement at ICAR-IARI, New Delhi is supported grants by the Indian Council of Agricultural Research (ICAR), Department of Biotechnology (DBT), Government of India, and Agricultural Processing and Export Development Authority (APEDA), Government of India.

\section{Availability of data and materials}

All relevant data are provided as Tables within the paper and in the Supporting Information files.

\section{Authors' contributions}

AKS, VPS and GKS conceived the projects, designed and supervised the overall research. RKE and GKS performed the experiments and analysis, GKS and RKE analyzed data. GKS, RKE, AKS, VPS and TM wrote the paper. All authors read and approved the final manuscript.

\section{Ethics approval and consent to participate}

This study complied with the ethical standards of India, where this research was carried out. 


\section{Consent for publication}

Not applicable.

\section{Competing interests}

The authors declare that they have no competing interests.

\section{Publisher's Note}

Springer Nature remains neutral with regard to jurisdictional claims in published maps and institutional affiliations.

\section{Author details}

${ }^{1}$ E-9, Sector 40, Noida, UP 201303, India. ${ }^{2}$ Division of Genetics, ICAR-Indian Agricultural Research Institute, New Delhi 110012, India. ${ }^{3}$ Indian Council of Agricultural Research (ICAR), New Delhi 110001, India.

Received: 23 November 2017 Accepted: 27 March 2018

Published online: 09 April 2018

\section{References}

Amarawathi $Y$, Singh $R$, Singh AK, Singh VP, Mahopatra T, Sharma TR, Singh NK (2008) Mapping of quantitative trait loci for Basmati quality traits in rice (Oryza sativa L.). Mol Breed 21:49-65

Anand D, Baunthiyal M, Gopala Krishnan S, Singh NK, Prabhu KV, Singh AK (2015) Novel InDel variation in GS3 locus and development of InDel based marker for marker assisted breeding of short grain aromatic Rices. J Plant Biochem Biotechnol 24:120-127

Anand D, Baunthiyal M, Singh A, Gopala Krishnan S, Singh NK, Prabhu KV, Singh AK (2013) Validation of gene based marker-QTL association for grain dimension traits in rice. J Plant Biochem Biotechnol 22:467-473

Anonymous (1910) 'Races of rice in India'. In: Agricultural ledger no. 1 Vol. XVI (the reports on economic products of the government of India ed.). Government printing press, Calcutta, pp. 48-49 \& 60-61

Babu NN, Gopala Krishnan S, Vinod KK, Krishnamurthy SL, Singh VK, Singh MP, Singh R, Ellur RK, Rai V, Bollinedi H, Bhowmick PK, Yadav A, Mariappan N, Singh NK, Prabhu K, Singh AK (2017) Marker aided incorporation of Saltol, a major QTL associated with seedling stage salt tolerance, into Oryza sativa 'Pusa basmati 1121'. Front Plant Sci 8:41. https://doi.org/10.3389/fpls.2017.00041

Ellur RK, Khanna A, Gopala Krishnan S, Bhowmick PK, Vinod KK, Nagarajan M, Mondal KK, Singh NK, Singh K, Prabhu KV, Singh AK (2016) Marker-aided incorporation of Xa38, a novel bacterial blight resistance gene, in PB 1121 and comparison of its resistance Spectrum with xa13+Xa21. Sci Rep 6:29188. https://doi.org/10.1038/srep29188

Ellur RK, Khanna A, Yadav A, Pathania S, Rajashekara H, Singh VK, Gopala Krishnan S, Bhowmick PK, Nagarajan M, Vinod KK, Prakash G, Mondal KK, Singh NK, Prabhu KV, Singh AK (2016) Improvement of basmati rice varieties for resistance to blast and bacterial blight diseases using marker assisted backcross breeding. Plant Sci 242:330-341

Fiyaz AR, Yadav AK, Gopala Krishnan S, Ellur RK, Bashyal BM, Grover N, Bhowmick PK, Nagarajan M, Vinod KK, Singh NK, Prabhu KV, Singh AK (2016) Mapping quantitative trait loci responsible for resistance to bakanae disease in rice. Rice 9:45. https://doi.org/10.1186/s12284-016-0117-2

Krishnan SG, Waters DLE, Katiyar SK, Sadananda AR, Satyadev V, Henry R (2012) Genome-wide DNA polymorphisms in elite indica rice inbreds discovered by whole-genome sequencing. Plant Biotechnol J 10:623-634

Ramaiah K, Rao MV (1953) Rice breeding and genetics. ICAR science monograph 19. Indian Council of Agricultural Research, New Delhi

Siddiq EA, Vemireddy LR, Nagaraju J (2012) Basmati Rices: genetics, breeding and trade. Agric Res 1:25-36

Singh AK, Ellur RK, Gopala Krishnan S, Bhowmick PK, Nagarajan M, Vinod KK, Haritha B, Singh VK, Khanna A, Pathania S, Yadav A, Mondal KK, Seth R (2018) Basmati rice variety Pusa Basmati 1718. Indian J Genet 78:151

Singh AK, Gopala Krishnan S, Nagarajan M, Vinod KK, Bhowmick PK, Atwal SS, Seth R, Chopra NK, Chander S, Singh VP, Prabhu KV, Singh D, Kumar S, Ravindran G (2014) Basmati rice variety, Pusa Basmati 1509. Indian J Genet 74:123

Singh AK, Gopala Krishnan S, Singh VP, Mohapatra T, Prabhu KV, Singh NK, Sharma TR, Nagarajan M, Vinod KK, Singh D, Singh UD, Chander S, Atwal SS, Seth R, Singh VK, Ellur RK, Singh A, Anand D, Khanna A, Yadav S, Goel N, Singh A, Shikari AB, Singh A, Marathi B (2011) Marker assisted selection: a paradigm shift in basmati breeding. Indian J Genet 71:1-9
Singh R, Singh AK, Sharma TR, Singh A, Singh NK (2007) Fine mapping of aroma QTLs in basmati rice (Oryza sativa L.) on chromosomes 3, 4 and 8. J Plant Biochem Biotechnol 16:75-82

Singh R, Singh AK, Sharma TR, Singh A, Singh NK (2012) Fine mapping of grain length QTLs on chromosomes 1 and 7 in basmati rice (Oryza sativa L.). J Plant Biochem Biotechnol 21:157-166

Singh VP, Pratik S, Gopala Krishnan S, Singh AK (2004) Role of Indian Agricultural Research Institute in genetic improvement of rice varieties in India. In: Sharma SD, Rao P (eds) Genetic improvement of rice varieties in India. Today and Tomorrow's printers and publications, India, pp 141-187

Singh VP, Siddiq EA, Zaman FU, Sadananda AR (1988) Improved basmati donors. Int Rice Res Newsl 13:22-25

Singh VP, Singh AK (2009) History of basmati rice research and development in India. Indian Farming 59(1):4-6

Singh VP, Singh AK (2010) Role of Indian Agricultural Research Institute in collection, acquisition, evaluation, enhancement, utilization and conservation of rice germplasm. In: Sharma SD (ed) Genetic resources of rice in India. Today and Tomorrow's printers and publications, India, pp 135-150

Singh VP, Singh AK, Atwal SS, Joseph M, Mohapatra T (2002) Pusa 1121: a rice line with exceptionally high cooked kernel elongation and basmati quality. Int Rice Res Notes 27:25-26

\section{Submit your manuscript to a SpringerOpen ${ }^{\circ}$ journal and benefit from:}

- Convenient online submission

- Rigorous peer review

- Open access: articles freely available online

- High visibility within the field

- Retaining the copyright to your article 